\title{
Behaviour of Reinforced Concrete Columns Strengthened with Ferrocement under Compression Conditions: Experimental Approach
}

\author{
Adnan Al-Sibahy \\ Civil Engineering Department, University of Al-Qadisiyah, Al Diwaniyah, Iraq \\ Email: Adnan.alsibahy@qu.edu.iq, Adnan_flayih@yahoo.com
}

How to cite this paper: Al-Sibahy, A. (2016) Behaviour of Reinforced Concrete Columns Strengthened with Ferrocement under Compression Conditions: Experimental Approach. World Journal of Engineering and Technology, 4, 608-622.

http://dx.doi.org/10.4236/wjet.2016.44057

Received: September 21, 2016

Accepted: November 27, 2016

Published: November 30, 2016

Copyright $\odot 2016$ by author and Scientific Research Publishing Inc. This work is licensed under the Creative Commons Attribution International License (CC BY 4.0).

http://creativecommons.org/licenses/by/4.0/

\begin{abstract}
This paper reports a study based upon experimental investigation which aims to assess the behaviour of reinforced concrete columns strengthened with a new configuration of steel wire mesh as part of ferrocement layer under the action of axial compression loads. Square and circular small scale columns with three different slenderness ratios of 5, 6.7 and 10 were adopted. A comprehensive experimental progarmme was then running to measure the load capacity and both lateral and vertical displacements. The failure mode was also monitored for each tested case. The results obtained was compared with the reference column samples (without wire mesh) and with some expressions suggested by ACI Code. The experimental results showed that the most influential parameter on the property of load carrying capacity is the slenderness of column. As the slenderness increases, the load capacity clearly decreases. The use of wire mesh enhanced the capability of column to resist the axial loads due to confinement role provided by such material. The maximum percentage increase in load carrying capacity for the modified columns compared with those for the reference samples was $53 \%$ for the circular column at slenderness ratio of 10 . The critical path of the failure mode was similar for all of the tested columns and normally began from the top or bottom ends, then, in some cases, passed through the middle zone of the column. A suitable expression was suggested to be used for calculating the modulus of elasticity of the tested column based upon the value of load carrying capacity under compression loads.
\end{abstract}

\section{Keywords}

Ferrocement, Concrete Columns, Compression Loads, Slenderness Ratios 


\section{Introduction}

Column members are mainly designed to resist the imposed axial loads of the structure and the global behaviour of such members depends upon the strength of the material used, nature of end supports and the length/ radius ratio. If the column is classified as a long column in which its cross-sectional dimensions are small compared with its length, then the propagated bending moments should be taken into consideration [1]. The main causes of the damaged concrete columns are the brittle behaviour, insufficient resistance to the shear transverse and relatively small length of lap-spliced of the hoops [2] [3] [4]. In some cases, the aforementioned factors combined, and then complete failure is occurred. Therefore, it is necessary to investigate the technique to strengthen the corroded column in order to improve its performance.

The traditional perception for increasing the compressive, bending and shear strengths of columns is by using longitudinal and transverse steel reinforcements. Some of the modern concepts have an orientation to modify the interior composition of columns, for instance using fiber-reinforced polymers (FRP), especially in strengthening the damaged once due to corrosion of steel reinforcement or other situations [3] [4]. However, this attitude incorporates increasing the cost of maintenance due to the high cost of FRP. The other way in improving the load carrying capacity of column adopting nowadays is by confining technique throughout a steel wire mesh. This technique is so called ferrocement which is usually applied with a cement mortar to act as an outer layer for the reinforced concrete column [5] [6] [7]. There are different configurations of the steel wire mesh with a small diameter reached to about $1.5 \mathrm{~mm}$. This leads to a higher specific surface resulting in higher bond strength with the mortar. Consequently, homogenous composition can be achieved with a minimal crack space when the ferrocement is applied as small thickness layer [6]. On this basis, some standards specify the minimum covers of ferrocement to be $5 \mathrm{~mm}$ when the concrete columns subjected to the environmental effect [5] [6] [7].

Many studies pointed out that the ferrocement technique involves improvements in tensile and flexural strengths, toughness, fracture, fatigue resistance and the impact resistance. This can be attributed to the uniform dispersion of reinforcement in the concrete matrix [5] [8]. As its components are available in worldwide combined with the low level of skill required to the fabrication, ferrocement is considered to be an appropriate confinement material for the structural elements. In such a manner, the core of column can be made with a concrete of relatively low compressive strength.

Although much attention has been bid in the field of enhancing the load carrying capacity of concrete columns, however, more efforts are need to investigate the effect of ferrocement composition on columns with different geometries. In this study, the behaviour of reinforced concrete columns under axial loads with different slenderness ratios and geometries strengthened with a thick steel wire mesh was investigated throughout experimental programme. The results obtained were compared with the reference column samples and with expressions suggested by the relevant codes of practice. Margins, column widths, line spacing, and type styles are built-in; examples of the type 
styles are provided throughout this document and are identified in italic type, within parentheses, following the example. Some components, such as multi-leveled equations, graphics, and tables are not prescribed, although the various table text styles are provided. The formatter will need to create these components, incorporating the applicable criteria that follow.

\section{Experimental Programme}

\subsection{Material Used}

Normal concrete formulated from ordinary Portland cement, natural sand for building purposes and crushed coarse aggregate with a nominal particle size of $5 \mathrm{~mm}$ were used in this study. The ordinary Portland cement compliant with ASTM C150-07 [9] manufactured by the Lafarge Company, while both of the fine and coarse aggregates satisfied the grading limits as required in ASTM C33-03 [10]. Table 1 illustrated the properties of cement, fine and coarse aggregates used in this study. The concrete was design to have a minimum compressive strength of $10 \mathrm{MPa}$ at 28-days age with workability of $120 \mathrm{~mm}$ slump. The reason for chosen this level of strength is to explore the effect of ferrocement in enhancing the load carrying capacity of columns. On this basis, 3 cubes of $150 \mathrm{~mm}$ were tested per each casting, as shown in Figure 1, and the results showed that the average compressive strength is $10.1 \mathrm{MPa}$.

BRC steel bars with a nominal diameter of $6 \mathrm{~mm}$ was used in reinforcing both longitudinal and lateral directions, as shown in Figure 2. The properties of BRC steel bars are presented in Table 2, and they comply with requirements of ASTM A615/A615M01b: Grad 40 [11].

A steel wire mesh with a thickness of about $1.5 \mathrm{~mm}$ and trapezoidal opening was used to formulate the ferrocement layer. It has a hard angle each $100 \mathrm{~mm}$ and was supplied as a roller of $1 \mathrm{~m}$ width, as shown in Figure 3. Table 2 shows the mechanical properties of the steel wire mesh used in this study. A cement mortar with a mix proportion of $1: 3$ by volume was adopted in constructed ferrocement layer.

Table 1. Properties of cement, fine and coarse aggregates used in this study.

\begin{tabular}{|c|c|c|c|c|c|c|c|c|}
\hline \multicolumn{3}{|c|}{ Ordinary Portland cement } & \multicolumn{3}{|c|}{ Fine aggregate } & \multicolumn{3}{|c|}{ Coarse aggregate } \\
\hline Property & $\begin{array}{l}\text { Test } \\
\text { result }\end{array}$ & $\begin{array}{c}\text { ASTM } \\
\text { C150-07 }\end{array}$ & $\begin{array}{l}\text { Sieve } \\
(\mathrm{mm})\end{array}$ & $\begin{array}{c}\% \\
\text { Passing }\end{array}$ & ASTM C33/03 & $\begin{array}{l}\text { Sieve } \\
(\mathrm{mm})\end{array}$ & $\begin{array}{c}\% \\
\text { Passing }\end{array}$ & $\begin{array}{c}\text { ASTM C33/03 } \\
(2.36-9.5 \mathrm{~mm})\end{array}$ \\
\hline 3 d-st. & 16.67 & $\geq 12 \mathrm{MPa}$ & 9.5 & 100 & 100 & 25 & 100 & - \\
\hline $7 \mathrm{~d}$-st. & 23.00 & $\geq 19 \mathrm{MPa}$ & 4.75 & 100 & $95-100$ & 19 & 100 & - \\
\hline $\mathrm{C} 2 \mathrm{~S}$ & $25.0 \%$ & - & 2.36 & 86 & $80-100$ & 12.5 & 100 & 100 \\
\hline C3S & $52.0 \%$ & - & 1.18 & 77 & $50-85$ & 9.5 & 100 & $85-100$ \\
\hline $\mathrm{C} 3 \mathrm{~A}$ & $11.8 \%$ & - & 0.60 & 51 & $25-60$ & 4.75 & 28 & $10-30$ \\
\hline $\mathrm{C} 4 \mathrm{AF}$ & $8.20 \%$ & - & 0.30 & 8 & $5-30$ & 2.36 & 5 & $0-10$ \\
\hline- & - & - & 0.15 & 2 & $0-10$ & 1.18 & 2 & $0-5$ \\
\hline \multicolumn{3}{|c|}{ Salts in terms of $\mathrm{SO}_{3}$} & \multicolumn{2}{|c|}{0.33} & $0.5 \%$ & \multicolumn{2}{|c|}{0.08} & $0.1 \%$ \\
\hline
\end{tabular}




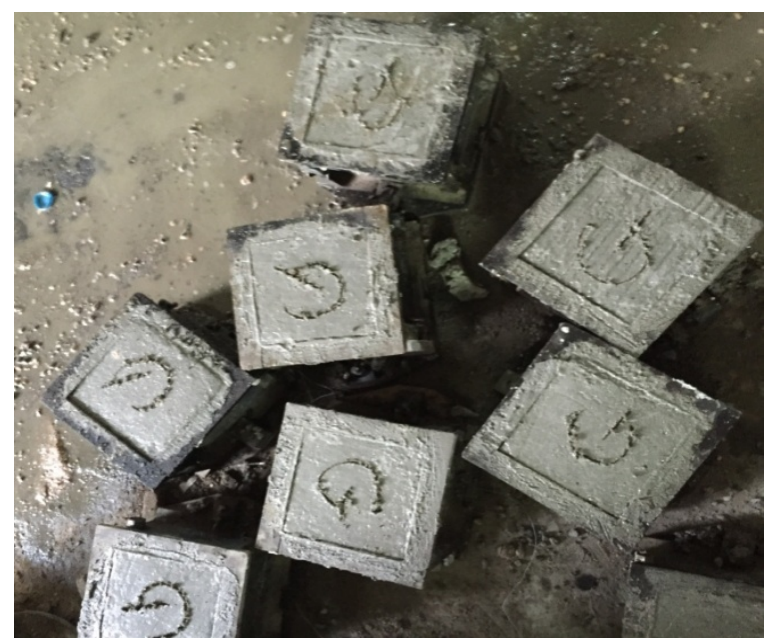

Figure 1. Casting the concrete cubes for the test of compressive strength.

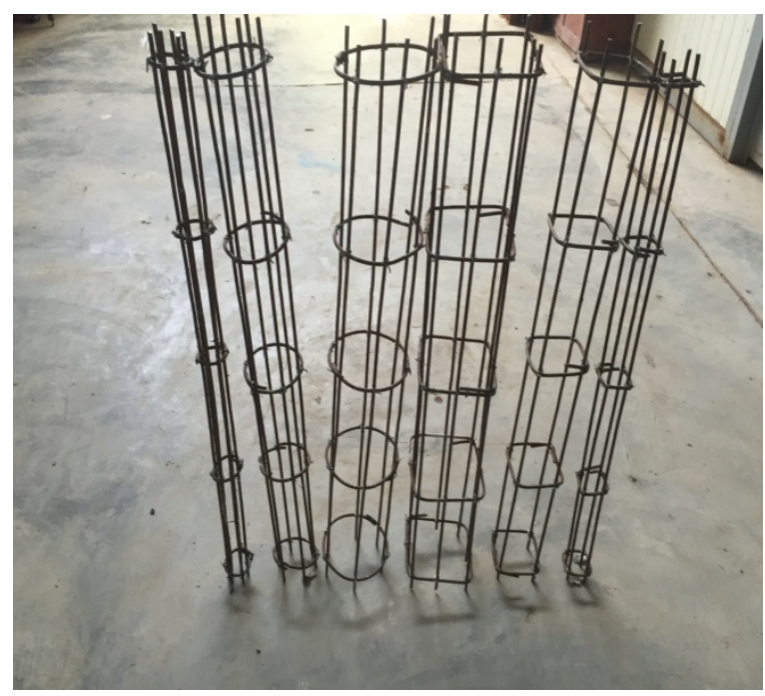

Figure 2. BRC steel bars used in the main reinforcement.

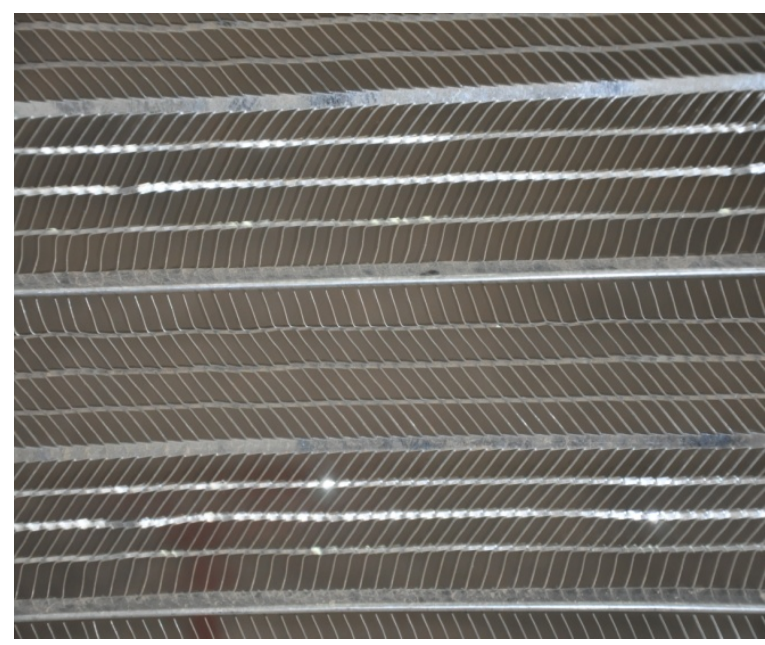

Figure 3. The steel wire mesh used to formulate the ferrocement layer. 
Table 2. Properties of BRC steel bars and wire mesh used in this study.

\begin{tabular}{cccc}
\hline Property & $\begin{array}{c}\text { BRC } \\
\text { steel bars }\end{array}$ & $\begin{array}{c}\text { Steel } \\
\text { wire mesh }\end{array}$ & $\begin{array}{c}\text { Limitation of } \\
\text { ASTM A615/A615M-01b: Grad 40 }\end{array}$ \\
\hline Tensile strength (MPa) & 778 & 560 & 420 \\
Yield strength (Mpa) & 380 & 305 & 280 \\
Elongation for length of $200 \mathrm{~mm}$ & 30 & 37 & - \\
\hline
\end{tabular}

\subsection{Casting the Columns}

Wooden and plastic moulds were designed to site the geometries of the concrete columns. All of the moulds were $1 \mathrm{~m}$ in height. The cross-section diameters of plastic moulds were $10 \mathrm{~cm}, 15 \mathrm{~cm}$ and $20 \mathrm{~cm}$, while the wooden moulds were formulated to have a rectangular cross-section with a side length of $10 \mathrm{~cm}, 15 \mathrm{~cm}$ and $20 \mathrm{~cm}$, as shown in Figure 4. Before running the casting process, the moulds were coated with oil and tied enough in order to prevent adhere the concrete and keeping the mixing water required for the cement hydration. The longitudinal steel bars were distributed within the column so that the minimum steel area is achieved for each geometry as per in ACI Code 10.9.1 [12]. Moreover, the spacing between steel bars was adjusted to be more than $3 / 4$ maximum size of aggregate and diameter of steel bar. For each column configuration, the transverse steel bars were distributed at $250 \mathrm{~mm} \mathrm{c} / \mathrm{c}$ meaning 4 stirrups along the column height. The concrete cover was kept to be $40 \mathrm{~mm}$. Figure 5 shows the geometries of the column samples and their reinforcement details. The ferrocement layer was then applied for the modified column samples with a thickness of about $1 \mathrm{~cm}$ and the wire mesh placed in form of jacket, as shown in Figure 6. In this study, the term "reference samples" refer the normal reinforced columns, while the term "modified samples" is used to refer to the reinforced columns incorporated ferrocement layer. The casting of the concrete was performed using a $0.1 \mathrm{~m} 3$ vertical portable mixer. After $24 \mathrm{~h}$ the samples were demoulded and curried using wiped polypropylene sheet until the date of the test and the average result of two specimens was taken for each test.

\subsection{Set-Up of the Axial Compressive Tests}

The load carrying capacity of the column specimens were measured using a manually controlled compression machine with a maximum load capacity of $2000 \mathrm{kN}$, as shown in Figure 7. A constant loading rate of $0.3 \mathrm{MPa} / \mathrm{s}$ was used throughout the tests. Load, vertical and lateral displacements were recorded until specimen failure and the maximum load in $\mathrm{kN}$ was recorded. Figure 8 shows the locations of the measured vertical and lateral displacements using linear potentiometers. Before placing the column samples in the testing machine, they were painted white in color in order to monitor the failure mode as shown in Figure 9.

\section{Results and Discussions}

The results obtained for the load carrying capacity of the column samples with different geometries and slenderness ratios are shown in Figure 10 and Figure 11. It can be seen 


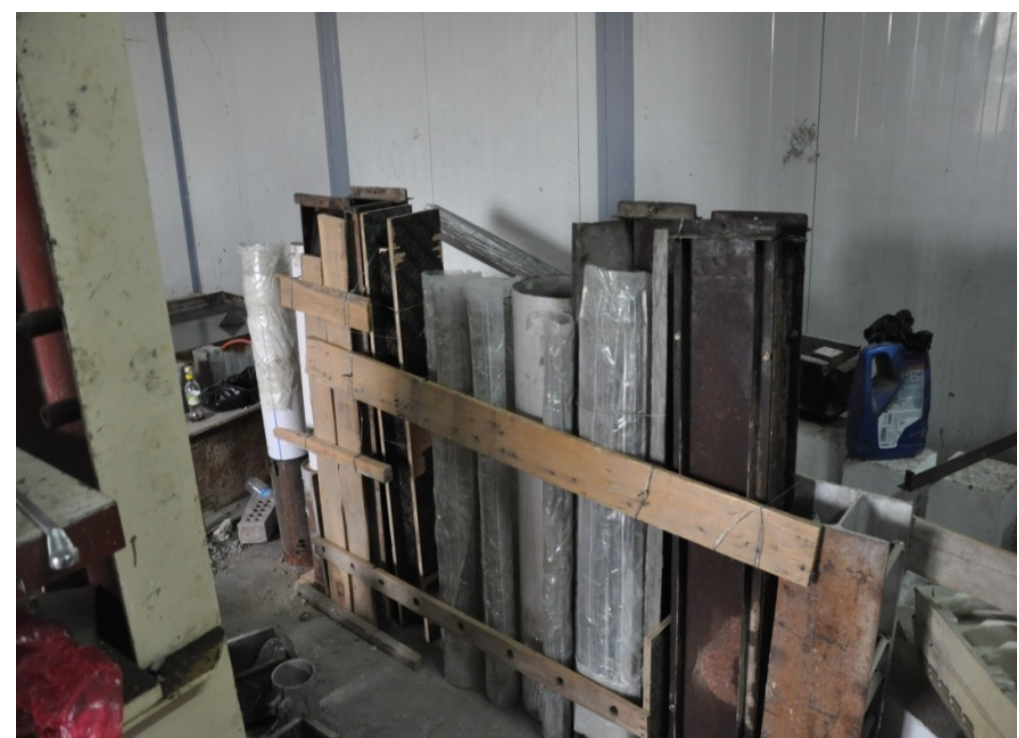

Figure 4. Preparing the moulds for casting process.

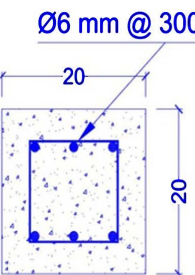

$6 \varnothing 6 \mathrm{~mm}$

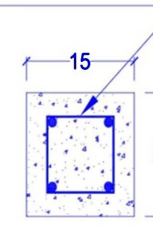

$4 \varnothing 6 \mathrm{~mm}$

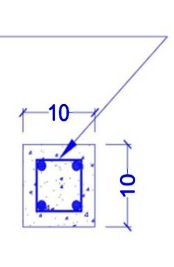

$4 \varnothing 6 \mathrm{~mm}$

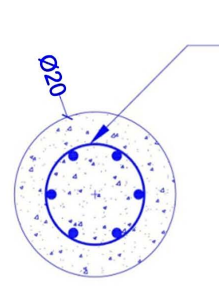

$6 \varnothing 6 \mathrm{~mm}$ $\varnothing 6$ mm @ 300 c/c

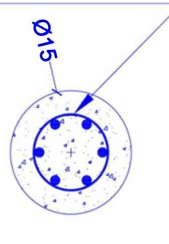

$6 \varnothing 6 \mathrm{~mm} \quad 6 \varnothing 6 \mathrm{~mm}$

Figure 5. The geometries of the column samples and their reinforcement details.

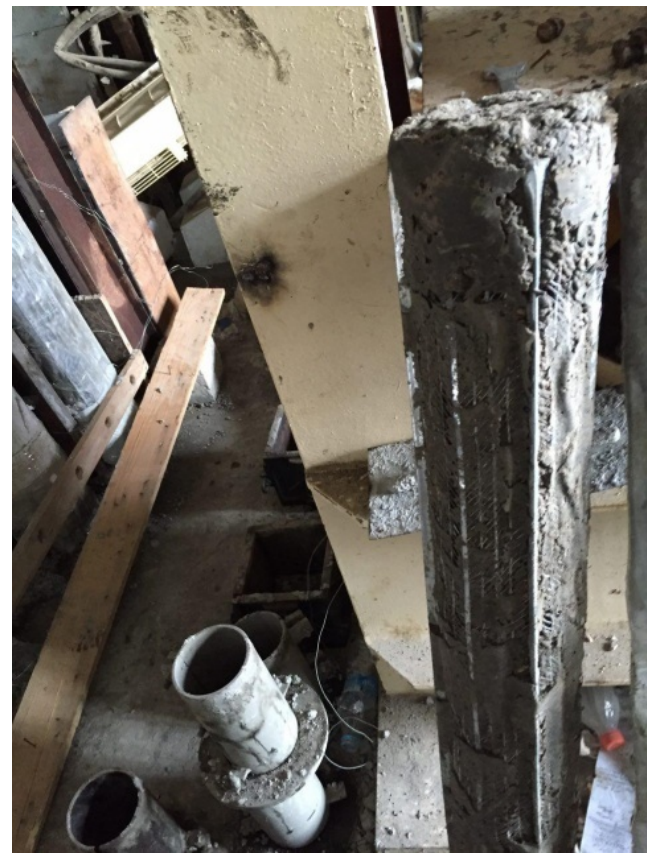

Figure 6. Applying the ferrocement layer to the concrete columns. 


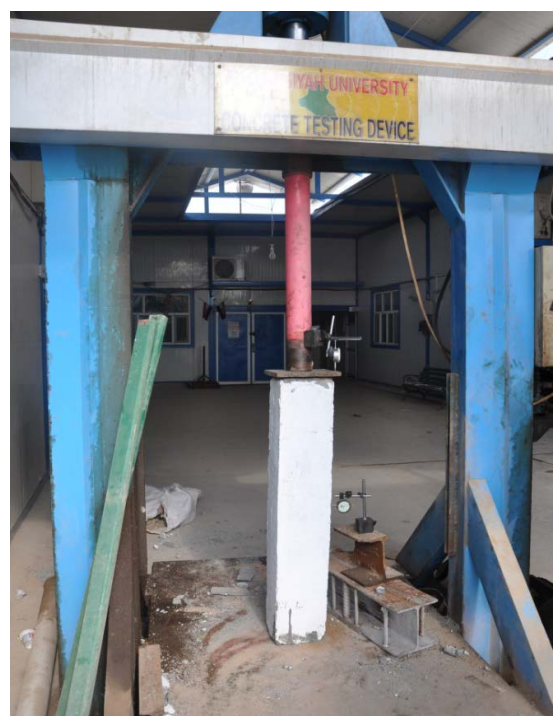

Figure 7. Manually controlled compression machine used in compression test.

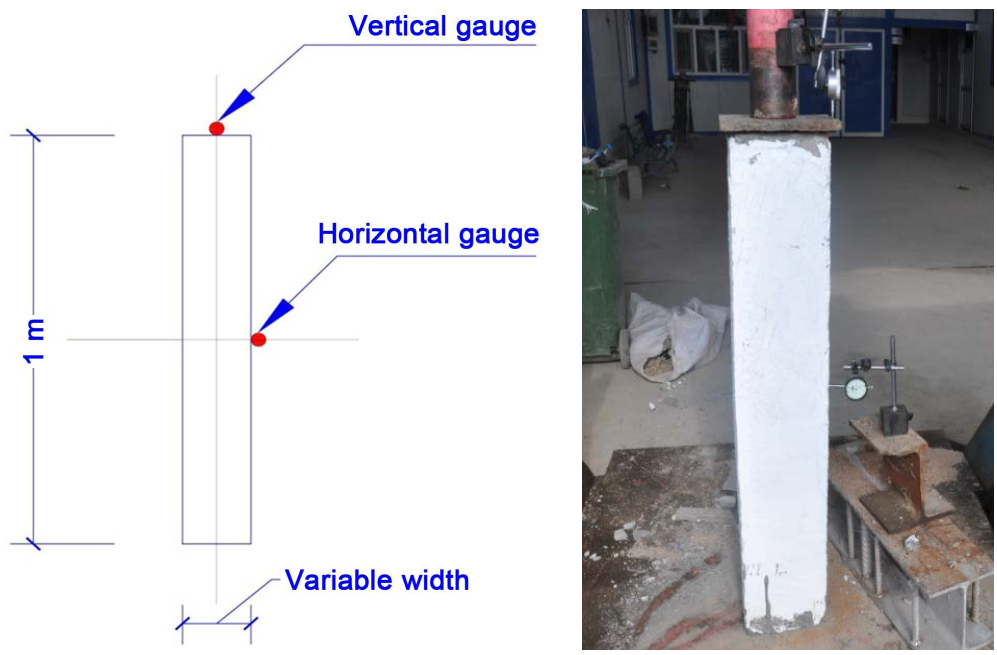

Figure 8. Locations of the linear potentiometers.

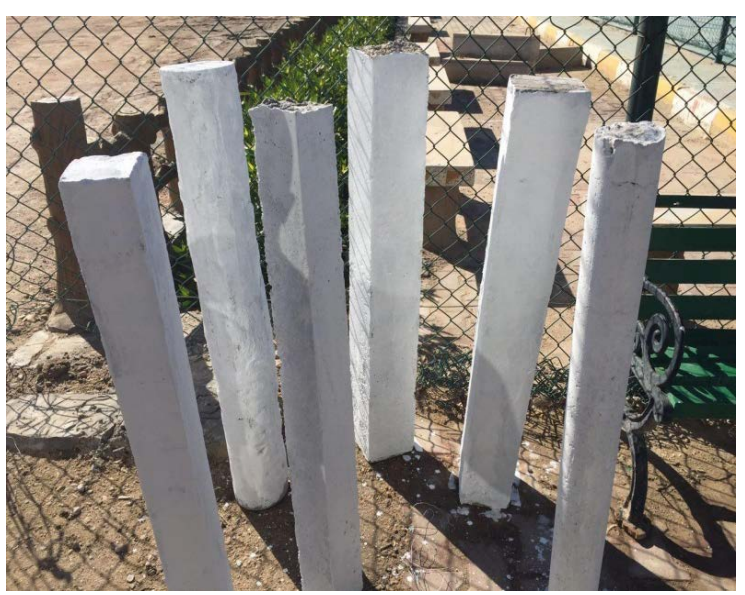

Figure 9. Painted the column samples before running the compressive test. 


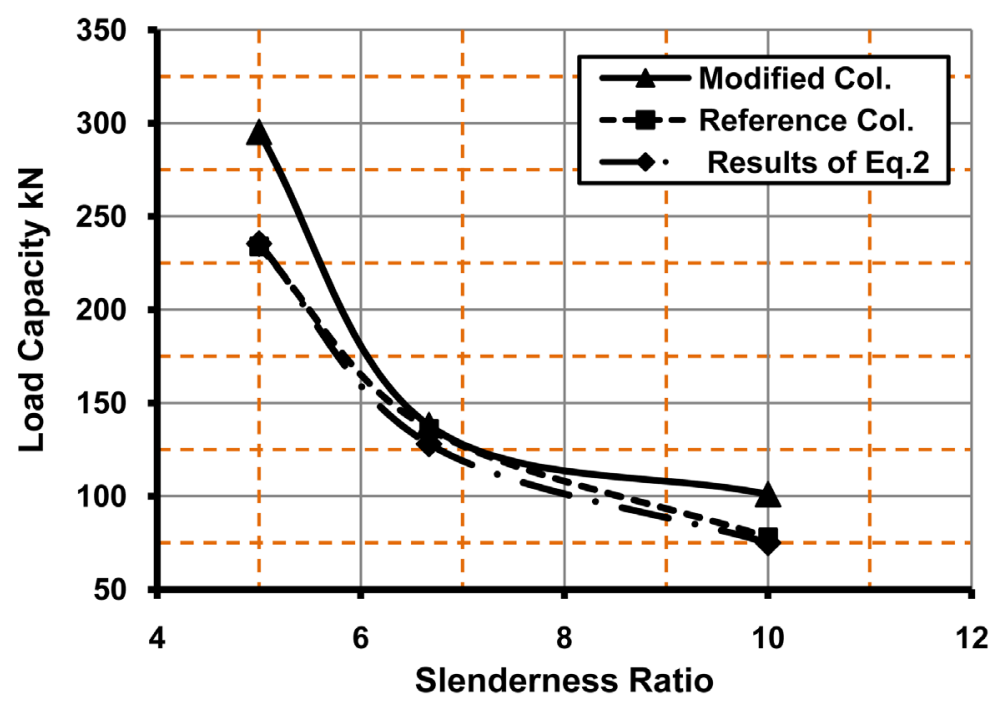

Figure 10. Load carrying capacity of the square columns for different slenderness ratios.

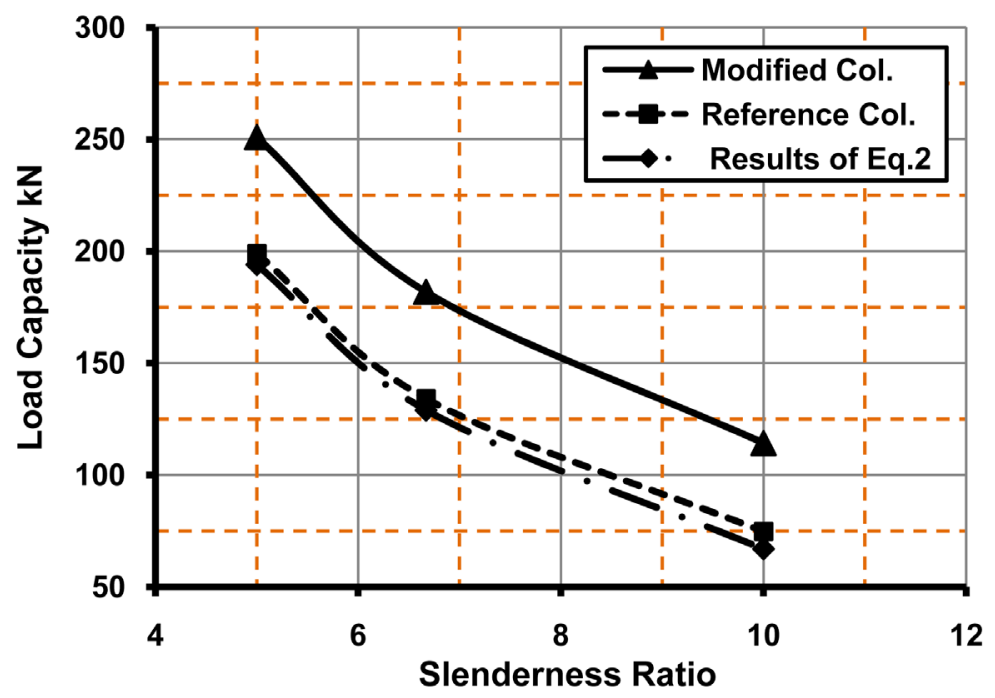

Figure 11. Load carrying capacity of the circular columns for different slenderness ratios.

that the slenderness ratio ( $1 / \mathrm{t}$ or $1 / \mathrm{d})$ has a major effect in determinate the load carrying capacity of all of the tested columns. As the slenderness ratio increases, the load capacity clearly decreases. This was expected due to the shear transverse associated with the column of high slenderness ratio which increases the probability of failure within a short term [3] [4]. In turn, column samples with lower slenderness ratios exhibited more capability to support the applied loads. On this basis, for design purposes [13], the slenderness effect on the wall or column behaviour can be introduced by multiplying the section capacity by a reduction factor, $R$, so that

$$
P_{\text {slender }}=A_{m} F_{m} R
$$

where

$$
P_{\text {slender }} \text { is the load carrying capacity of slender column; }
$$


$A_{m}$ is the cross-sectional area of the reinforced concrete column;

$F_{m}$ is the compressive strength of the reinforced concrete column; and

$R$ is a reduction factor due to the effect of slenderness.

It was obviously the increasing in load carrying capacity for the modified column samples in comparison with those of reference samples for both square and circular geometries. In except for the square column with slenderness ratio of 6.7, the former increases seem to be ascending linearly with the slenderness ratio. This attitude may be explained by the confinement effect of wire mesh which enhance the lateral resistance, thus the sustain capacity of axial the load will increase.

Percentage increases in load carrying capacity for square modified columns compared with those of reference samples with slenderness ratios of 5, 6.7 and 10 reached $25 \%, 7 \%$ and $35 \%$ respectively. The corresponding percentage increases for the circular columns were $26 \%, 35.5 \%$ and $53 \%$ respectively.

It would be interested to mention that the square columns showed more load carrying capacity than those of circular sections. The maximum value of load carrying capacity for the square columns was $295 \mathrm{kN}$ at slenderness ratio of 5, while the corresponding value for the circular columns was $235 \mathrm{kN}$ at the same level of slenderness ratio. This difference may be attributed to two aspects: the first is the contact area of square sample with the upper platen of testing machine is more, consequently more confinement is obtained. The second is due to high potential of square samples to resist the lateral expansion resulting in more axial load carrying capacity.

For normal reinforced concrete columns (reference samples), the code of practice [14] suggests Equation (2) to predict the load carrying capacity of the axially loaded columns:

$$
\varnothing P_{n \max }=0.85 \varnothing\left(0.85 f_{c}^{\prime}\left(A_{g}-A_{s t}\right)+f_{y} A_{s t}\right)
$$

where

$P_{n \max }$ is the maximum factored load capacity of the column;

$\varnothing$ is a reduction factor depends upon the quality control and other circumstances and recommended to be 0.65 ;

$f_{c}^{\prime}$ is the compressive strength of the concrete;

$A_{g}$ is the gross area of column;

$A_{s t}$ is the area of steel reinforcement; and

$f_{y}$ is the yield strength of steel (for grad $40=280 \mathrm{MPa}$ ).

The calculated results of load carrying capacity according to Equation (2) are presented in Figure 10 and Figure 11 in combined with the experimental measurements of both reference and modified column samples. Slight differences were observed between the calculated and measured results for the reference column samples. This manner may be due to the imperfection effect which involves small eccentricities in applying the axial load in addition to the deviation in the level of quality control. Some of codes of practice [15] set out the maximum value of construction or loading imperfection to be $\left(h_{e f} / 450\right)$. Besides, there was clear variation between the values of load car- 
rying capacity of the modified columns compared with those calculated results from Equation (2). This behaviour shows the role of wire mesh in increasing the resistance of column to lateral deformation due to the uniform dispersion of reinforcement in the concrete matrix [5] [8].

Based upon the aforementioned results, the area of stirrup reinforcement can be reduced by the amount of increasing in the load carrying capacity when the wire mesh is used. Applying the equation for the confining effect on the compressive strength of the spiral column suggested by [16] with some modifications to suite the ferrocement case, the reduction in the area of stirrup reinforcement can be express as follow:

$$
f_{2}^{\prime}=\grave{f}_{c m}-\grave{f}_{c}^{\prime}
$$

and

$$
A_{s m}=\frac{d_{c} f_{2}^{\prime}}{2 f_{y}}
$$

where

$f_{2}^{\prime}$ is the lateral confinement stress in core concrete produced by wire mesh;

$\grave{f}_{c m}$ is the compressive strength of column containing tie stirrup and wire mesh;

$f_{c}^{\prime}$ is the compressive strength of column containing tie stirrup only;

$A_{s m}$ is the cross-sectional area of wire mesh;

$d_{c}$ is the outside diameter of wire mesh; and

$f_{y}$ is the yield strength of wire mesh.

Figure 12 and Figure 13 show the results obtained for the vertical and lateral displacements against the slenderness ratio for both reference and modified columns with different geometries. It can be seen that the value of lateral displacement linearly related

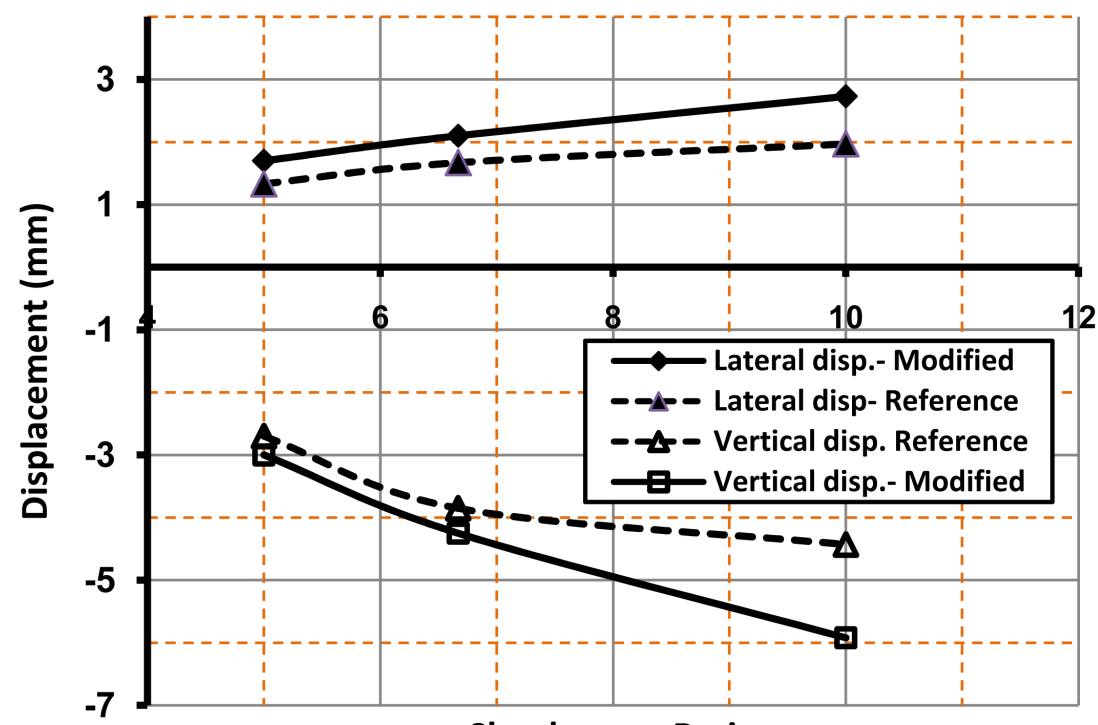

Slenderness Ratio

Figure 12. Lateral and vertical displacements of square columns for various slenderness ratios. 


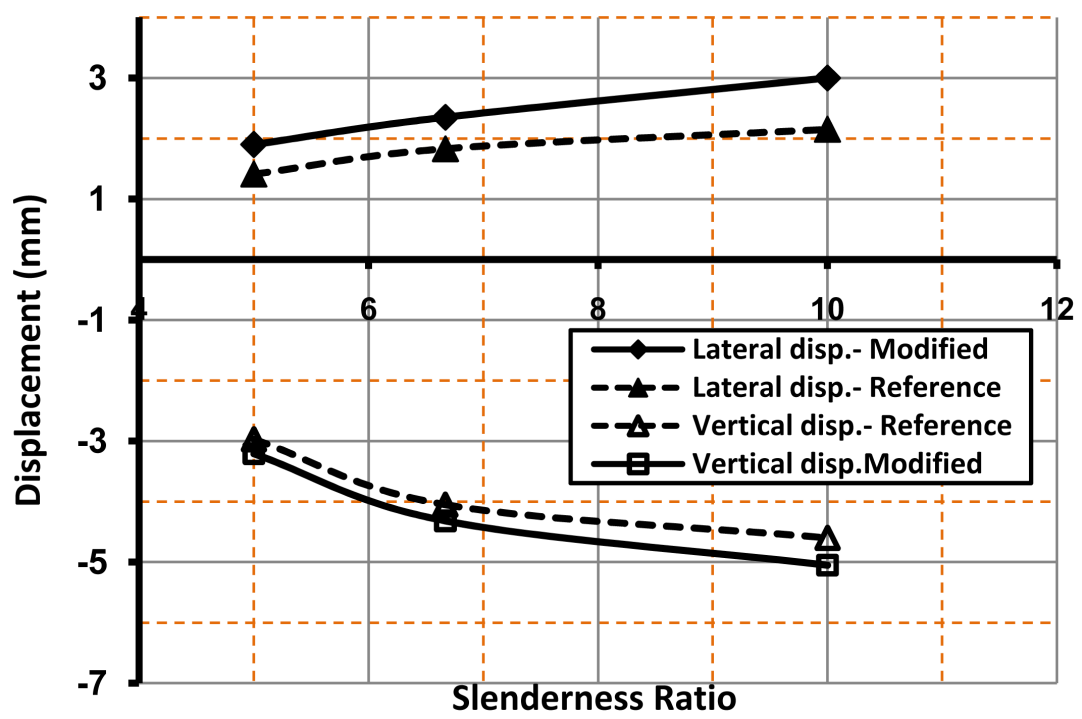

Figure 13. Lateral and vertical displacements of square columns for various slenderness ratios.

with the increasing in slenderness ratio of column. Same behaviour was also noted for the vertical displacement. This is well known when columns tend to fail under axial loads due to influence of tensile stresses propagated at mid height of column. In general, square columns exhibited less vertical and lateral deformations than those for circular columns. These results consistence with those obtained for the load carrying capacity and can be explained by the capability of square section to accommodate the deformations under the applied loads. Moreover, modified columns showed greater values of deformations compared with those for the reference samples for both section geometries. This indicative for the effect of wire mesh which led to increase the ductility of column and allows for more deformation to occur before complete failure.

The maximum vertical and lateral displacements were reordered for modified square columns at $6 \mathrm{~mm}$ and $3 \mathrm{~mm}$ respectively.

Consideration of the stress-strain characteristics of the column samples, the modulus of elasticity can be calculated. To achieve this, the average vertical strains and their corresponding compression stresses were considered. The strain value was calculated by dividing the average vertical displacement over the total height of the column (1000 $\mathrm{mm}$ ), and the results obtained showed that the values of modulus of elasticity for reference and modified column samples were in range of $1900 \mathrm{MPa}$ and $2300 \mathrm{MPa}$ respectively. Nevertheless, both of them have an equivalent ratio to their compressive strength of the order of 260.

In terms of the failure mode, the results obtained for all of the tested columns are shown in Figures 14-19. Most of the column samples behaved as a short column where no middle buckling observed during the tests. The global failure was due to crushed or fragmented of concrete near the ends of the sample. This attitude may be related to the restriction effect provided by the platen of testing machine at supports which led to propagate the cracks at the top or bottom end of the column and continue to a certain 


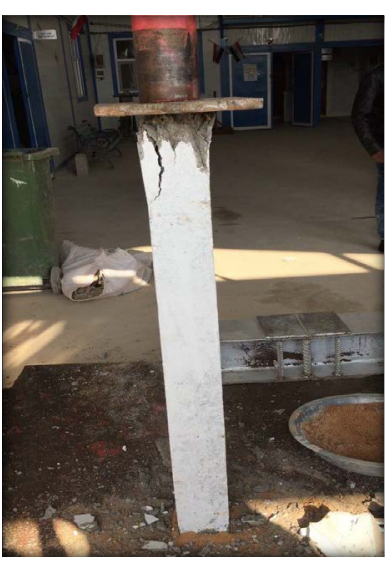

(a)

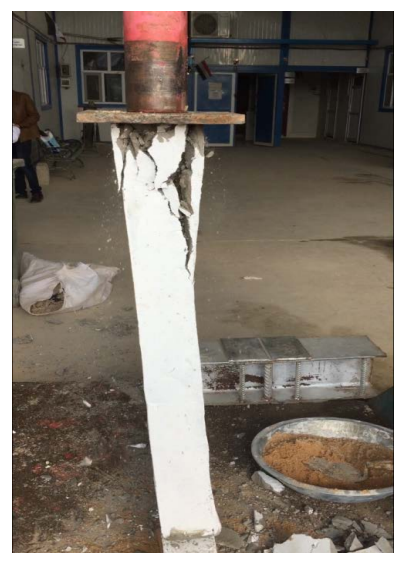

(b)

Figure 14. Failure mode of square columns with slenderness ratio $(1 / t=10)$ : (a) Reference sample (b) Modified sample.

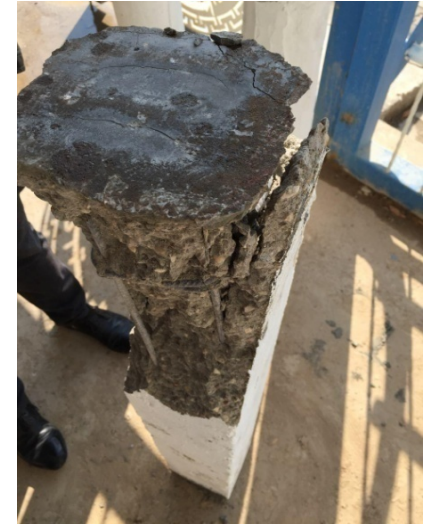

(a)

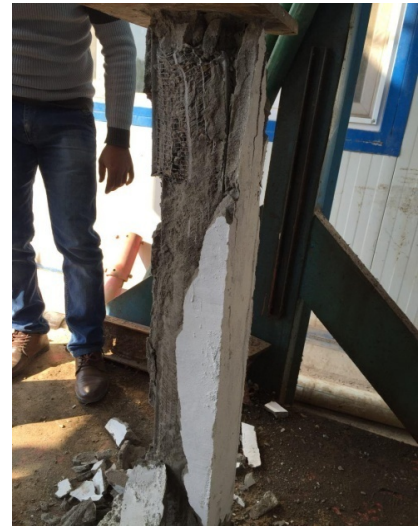

(b)

Figure 15. Failure mode of square columns with slenderness ratio $(1 / t=6.7)$ : (a) Reference sample (b) Modified sample.

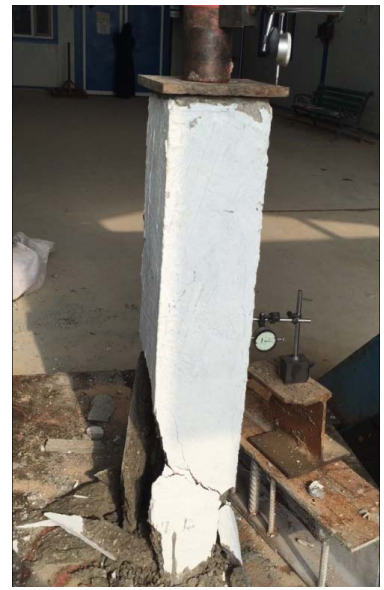

(a)

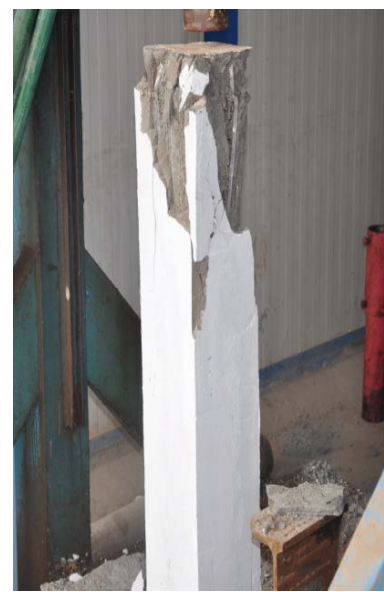

(b)

Figure 16. Failure mode of square columns with slenderness ratio $(1 / t=5)$ : (a) Reference sample (b) Modified sample. 


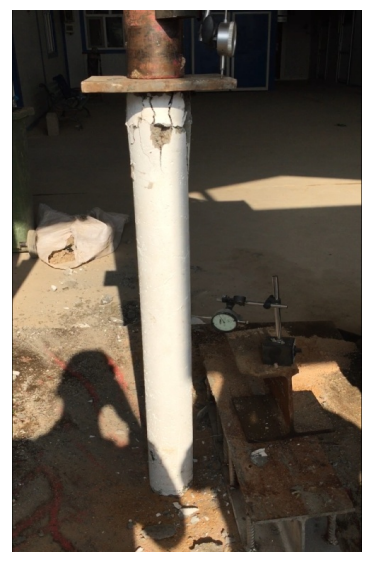

(a)

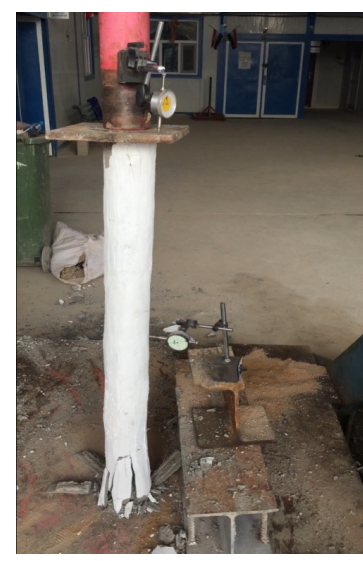

(b)

Figure 17. Failure mode of circular columns with slenderness ratio ( $1 / \mathrm{d}=10)$ : (a) Reference sample (b) Modified sample.

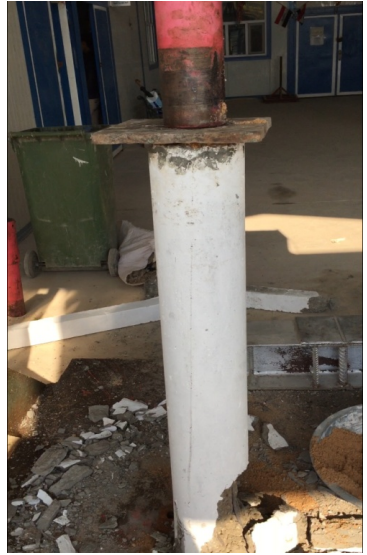

(a)

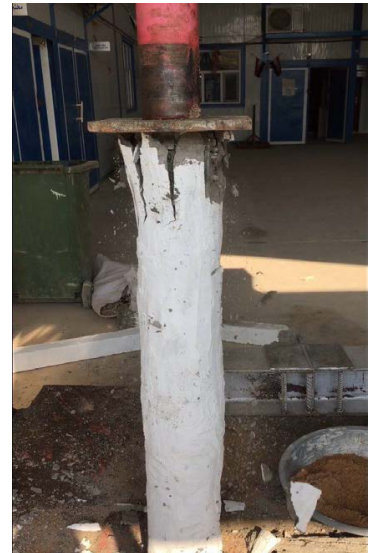

(b)

Figure 18. Failure mode of circular columns with slenderness ratio $(1 / \mathrm{d}=6.7)$ : (a) Reference sample (b) Modified sample.

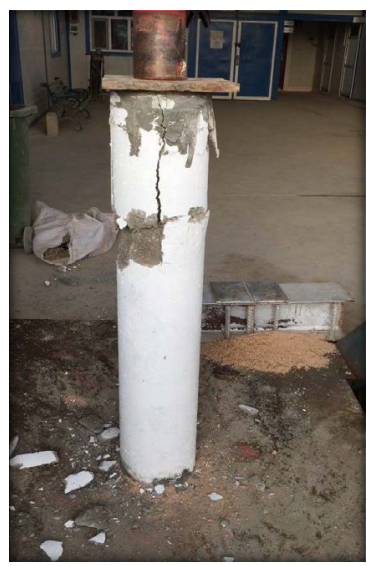

(a)

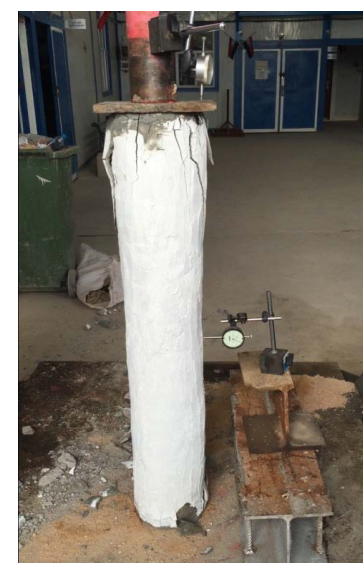

(b)

Figure 19. Failure mode of circular columns with slenderness ratio $(1 / d=5)$ : (a) Reference sample (b) Modified sample. 
limit of effected zone. However, the modified column samples tend to be more ductile than reference samples and the failure usually occur in the outer ferrocement layer, as shown in Figure 15(b). In contrast to the modified samples, some of the reference columns suffered from severe spalling of core concrete due to the less confinement provided by the tie stirrups, as shown in Figure 15(a). In some cases, the longitudinal steel reinforcements showed buckling behaviour at the top end of the columns as shown in Figure 14(a), Figure 15(a), Figure 15(b), Figure 18(b), Figure 19(a) and Figure 19(b).

\section{Conclusions}

This study was undertaken to evaluate the behaviour of reinforced concrete columns with different geometries enhanced by a ferrocement layer under axial compression loads based upon the experimental approach. The main significant findings of this study can be summarised as follows:

1. The slenderness was the most governing parameter on the behaviour of concrete columns under axial compression loads. The load carrying capacity of column was clearly decreased with an increase of slenderness ratio.

2. A notable improvement in the values of load carrying capacity of the column samples is containing wire mesh when they compare with those obtained for the reference samples.

3. For both reference and modified samples, the square columns exhibited higher load capacity than those for the circular columns. Such behaviour results from more contact area of square samples as well as their higher potential to resist the lateral expansions.

4. Identical behaviour was noted for both vertical and lateral displacements where they seem to be increased with an increase of slenderness ratio.

5. The modulus of elasticity of the tested columns can be approximately calculated as 260 multiplied by the value of the compressive strength for each specified column.

6. In general, the failure mode starts to propagate at the upper or lower end of the sample then continues to a certain zone based on the ductility of the tested column. All of the tested samples tend to be as a brittle material under the action of axial loads.

\section{References}

[1] Ailson, A.H. and Darwin, D. (1997) Design of Concrete Structures. 5th Edition, McGrawHill.

[2] Li, J.B., Gong, J.X. and Wang, L.C. (2009) Seismic Behavior of Corrosion-Damaged Reinforced Concrete Columns Strengthened Using Combined Carbon Fiber-Reinforced Polymer and Steel Jacket. Construction and Building Materials, 23, 2653-2663. http://dx.doi.org/10.1016/j.conbuildmat.2009.01.003

[3] Zhou, X.H. and Liu, J.P. (2010) Seismic Behavior and Strength of Tubed Steel Reinforced Concrete (SRC) Short Columns. Journal of Constructional Steel Research, 66, 885-896. http://dx.doi.org/10.1016/j.jcsr.2010.01.020 
[4] Polies, W., Ghrib, F. and Sennah, K. (2010) Rehabilitation of Interior Reinforced Concrete Slab-Column Connections Using CFRP Sheets. Construction and Building Materials, 24, 1272-1285. http://dx.doi.org/10.1016/j.conbuildmat.2009.12.008

[5] Kondraivendhan, B. and Pradhan, B. (2009) Effect of Ferrocement Confinement on Behavior of Concrete. Construction and Building Materials, 23, 1218-1222.

http://dx.doi.org/10.1016/j.conbuildmat.2008.08.004

[6] Xiong, G.J., Wu, X.Y., Li, F.F. and Yan, Z. (2011) Load Carrying Capacity and Ductility of Circular Concrete Columns Confined by Ferrocement Including Steel Bars. Construction and Building Materials, 25, 2263-2268. http://dx.doi.org/10.1016/j.conbuildmat.2010.11.014

[7] Abdullah, K.T. (2003) An Investigation into the Behavior and Strength of Reinforced Concrete Columns Strengthened with Ferrocement Jackets. Cement \& Concrete Composites, 25, 233-242. http://dx.doi.org/10.1016/S0958-9465(02)00005-7

[8] Harajli, M.H. (2007) Cyclic Response of Concrete Members with Bond-Damaged Zones Repaired Using Concrete Confinement. Construction and Building Materials, 21, 937-951. http://dx.doi.org/10.1016/j.conbuildmat.2006.05.002

[9] ASTM C150-07: Standard Specification for Portland Cement. ASTM Standards, 2007.

[10] ASTM C33-03: Standard Specification Concrete Aggregates. ASTM Standards, 2003.

[11] ASTM A615/A615M-01b: Deformed and Plain Billet-Steel Bar for Concrete Reinforcement. ASTM Standards, 2000

[12] (1994) ACI Code Detailing Manual, ACI Special Publication SP-66. American Concrete Institute, Farmington Hills, MI.

[13] Drysdale, R.G. and Hamid, A.A. (2008) Masonry Structures Behavior and Design. 3rd Edition, The Masonry Society.

[14] (1990) Design Handbook, Vol. 2, Columns, ACI Special Publication SP-17. American Concrete Institute, Farmington Hills, MI

[15] BS EN 1996-1-1 Eurocode 6. Design of Masonry Structures: Part 1-1: Common Rules for Reinforced and Unreinforced Masonry Structures. British Standards, 2005.

[16] Richart, F.E., Brandtzaeg, A. and Brown, A. (1929) The Failure of Concrete of Plain and Spirally Reinforced Concrete in Compression, Univ. III. Eng. Exp. Stn. Bull., 190.

Submit or recommend next manuscript to SCIRP and we will provide best service for you:

Accepting pre-submission inquiries through Email, Facebook, LinkedIn, Twitter, etc.

A wide selection of journals (inclusive of 9 subjects, more than 200 journals)

Providing 24-hour high-quality service

User-friendly online submission system

Fair and swift peer-review system

Efficient typesetting and proofreading procedure

Display of the result of downloads and visits, as well as the number of cited articles

Maximum dissemination of your research work

Submit your manuscript at: http://papersubmission.scirp.org/

Or contact wjet@scirp.org 